\title{
An overview of gender responsive budgeting in India
}

\author{
Smitha E. K ${ }^{1}$, N Karunakaran ${ }^{2 *}$ \\ ${ }^{\mathbf{1}}$ Assistant Professor, ${ }^{2}$ Principal and Research Guide, ${ }^{\mathbf{1}}$ Dept. of Economics, Government College, Madappally, Kozhikode, Kerala, India, \\ ${ }^{2}$ Economics of Kannur University, People Institute of Management Studies (PIMS), Kasaragod, Kerala, India
}

\section{*Corresponding Author: N Karunakaran}

Email: narankarun@gmail.com

\begin{abstract}
Gender budgeting has been well-acclaimed as a key tool for empowering women as it incorporates gender perspectives, and considers issues related to gender at all levels and phases of development, planning, policy making, programmes, and delivery mechanisms. Additionally, it effectively addresses gender gaps in budget allocations, especially in representative areas such as education, health, and employment. Gender budgeting aims at enabling access to resources and ensures that government resources are allocated fairly amongst all. Gender budgeting is thus creating new horizons of women empowerment. The concept of gender budgeting is becoming crucial and essential in the current Indian context as women are secluded, underestimated, and marginalised on numerous grounds.
\end{abstract}

Keywords: Gender budgeting, Gender equality, Women empowerment.

\section{Introduction}

As women constitute half of the population in India, ensuring gender equality and empowerment of women are catalysts for the rapid economic advancement. As India is basically patriarchal, overall human development will only be possible with the empowerment of women who currently lag far behind their male counterparts in terms of education, health, earnings and decision making both at household and administrative levels. As per the Global Gender Gap Index, India was ranked $114^{\text {th }}$ out of 142 countries in 2015 , and India keeps on slipping on the Global Gender Gap Index from $108^{\text {th }}$ position in 2019 to $112^{\text {th }}$ position among 153 countries in 2020. Sidelining women and girls in India from sharing the fruits of growth and development will thwart the prospects of the country in the long run as sustainable development of the economy largely relies upon the socioeconomic advancement of women. Hence, a nation which cherishes the dream of developed status cannot afford the underutilisation of female human resources which comprise 48.43 percent of total human resources. Therefore, opening up opportunities for women can play a prominent role in the process of accomplishing the developmental objective.

An overview of women in India demonstrates that they encounter various forms of vulnerability throughout the life cycle. Most of them face discrimination even before birth and it continues until their last breath; violence, harassment or abuse; neglect due to dependence and lack of access to resources; social prejudice; and exploitation; whether economic, political, social or religious are few to mention (Gender budgeting handbook, 2015). The violence against women and girls persists even today, both in private and public spheres. The brutality against women keeps on hiking, though it takes multiple forms - domestic violence, rape, trafficking, and child abuse, sexual harassment in the workplace, harassment and lack of safety in public places and while traveling. To tackle the issue of violence against women and also to ensure gender equality there is an urgent call for specific policy intervention from the government.
Gender responsive budgeting is one such initiative by the Government of India to ensure female empowerment.

Gender-responsive budgeting refers to a method of looking at the budget formulation process, budgetary policies and budget outlay through the gender lens. It is an analytical device which scrutinizes the government budget to uncover its gender-differentiated impact and advocates for greater priorities for projects and schemes to address the gender-based discrimination and disadvantages faced by women. The fundamental objective of gender budgeting is to refine budgets and related strategies to enable gender equality (Singh Awdesh Kumar, 2010).

Consequently, the Government of India introduced a National Policy for Empowerment of Women in 2001 which pointed towards achieving advancement and empowerment of women. The significant objectives of the policy were to eliminate all forms of discrimination against women and to ensure their dynamic participation in public and private spaces. Likewise, gender budgeting is also widely acknowledged as a powerful tool for empowerment of women. The union budget for 2005-06 included, for the first time, a separate statement on the gender sensitivity of budgetary allocations in ten demands for Grants. Since 2005-06, the Expenditure Division of the Ministry of Finance has been issuing a note on Gender Budgeting as a part of the Budget Circular every year which is compiled and incorporated in the form of Statement 20 in the Expenditure Budget Document.

The Gender Budget Statement (GBS) comprises two parts; Part A and Part B. Part A reflects Women-Specific schemes, which have a 100 percent allocation for women, while Part B reflects Pro-Women schemes, which include those with at least 30 percent of the allocation for women (Government of India, 2016). The Women-Specific Schemes and Pro-women Specific Schemes are spread across a broader spectrum as they incorporate women's need for shelter, security, wellbeing, legal aid, justice, information, maternal health, food, nutrition, as well as their need for economic sustenance through skill development, 
education and access to credit and marketing. Taking this into account, the paper analysed the trend and magnitude of budgetary allocations for schemes/programmes that substantially benefit women in gender budgeting statements in India from 2005-06 to 2020-21.

\section{Materials and Methods}

Kalyani Menon and Seeta Prabhu K (2001) analysed the Union Budget 2001-2002 and found that the impact of investments in public goods and services was different on men and women. Nirmala Banerjee and Poulami Roy (2004) list different women-oriented schemes introduced in West Bengal. Poonam Sharma and Prabha Garg (2014) provided a broad outline of gender budgeting initiatives in India. Kapil Singh (2016) analysed the status and budget allocations for women and how gender budgeting benefit women to get an overview of the government's stand regarding the uplift of women. Singh A. K. and Kumar Ravish (2010) examined the gender-oriented perspective in development. Misra Roli (2010) also eliminated the inequalities faced by women and established the empowerment of women and expose the true spirit of gender budgeting. Anjali Goyal (2010), Mishra Y and Jhamb B (2015) and Archana Soni (2018) measured the effectiveness of Gender Budgeting in ensuring women empowerment. For analysis, this study used secondary data taken from the gender budgeting statements of the Government of India and the annual publications of the Ministry of Women and Child Development.

\section{Results, Analysis and Discussion Gender development in Indian planning}

The holistic development of women has been one of the focal points of planning process in India. The establishment of the Central Social Welfare Board, organization of Mahila Mandals and the Community Development Programmes were a few steps in the direction of welfare during the First Five-Year Plan. In the Second Five-Year Plan, the empowerment of women was closely linked with the overall approach of intensive agricultural development programmes. The Third and Fourth Five-Year Plans endorsed female education; and the Fifth Five-Year Plan emphasized training of women as a major welfare measure. In 1976, the Women's Welfare and Development Bureau was established under the Ministry of Social Welfare. The Sixth Five-Year Plan saw a definite shift from welfare to development. The Seventh Five-Year Plan illustrated the need for gender equality and empowerment. In 1986, the Department of Women and Child Development (DWCD), under the Ministry of Human Resource Development was entrusted with the responsibility of monitoring 27 beneficiary oriented schemes under various sectors that directly benefited women. The Eighth Five-Year Plan concentrated on empowering women, especially at the grass roots level, through Panchayat Raj Institutions. The Ninth Five-Year Plan implemented a strategy of women's component plan, under which not less than 30 percent of funds/benefits were earmarked for women-specific programmes. The Tenth Five-Year Plan aimed at empowering women by enacting the National Policy for Empowerment of Women (2001) and ensuring survival, protection and development of women and children through rights-based approach (Awdesh Kumar Singh, 2010). The Eleventh Five Year Plan envisaged the incorporation of Gender Budgeting beyond traditional areas to genderneutral sectors. The Twelfth Plan noted that one of the fundamental elements for Gender Equity was "Mainstreaming gender through Gender Budgeting".

Table 1: Gender budgeting as a percentage to GDP in India

\begin{tabular}{|c|c|}
\hline Year & $\begin{array}{c}\text { Gender budgeting as a percentage to } \\
\text { GDP (in percentage) }\end{array}$ \\
\hline $2008-09$ & 0.88 \\
\hline $2009-10$ & 0.87 \\
\hline $2010-11$ & 0.86 \\
\hline $2011-12$ & 0.90 \\
\hline $2012-13$ & 0.79 \\
\hline $2013-14$ & 0.76 \\
\hline $2014-15$ & 0.69 \\
\hline $2015-16$ & 0.59 \\
\hline $2016-17$ & 0.63 \\
\hline $2917-18$ & 0.54 \\
\hline $2018-19$ & 0.61 \\
\hline $2019-20$ & 0.63 \\
\hline $2020-21$ & 0.64 \\
\hline $\begin{array}{l}\text { Source: Various Union Budget Documents of Govt. of } \\
\text { India }\end{array}$ \\
\hline
\end{tabular}

Gender budgeting as percentage to GDP in India

The overall Gender Budget has remained below 1 percent of the gross domestic product and less than 5 percent of the total expenditure during 2008-09 to 2020-21 (Table 1 and Fig. 1). The legitimacy of such allocations is another dimension to the issue of inadequate funds. Between 200809 and 2019-20, the actual or revised expenditure on schemes exclusively for women was lower than the budgeted estimates.

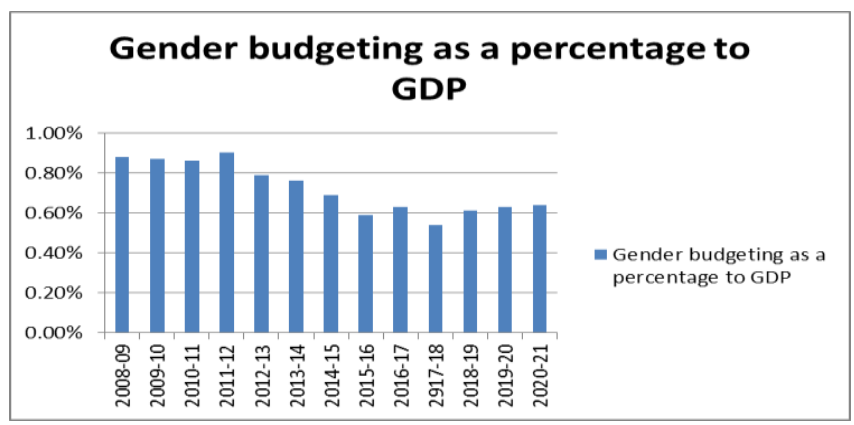

Figure 1: Gender budgeting as a percentage to GDP in India (Source: Computed from Table 1)

\section{Magnitude of gender budgeting in India}

Over time, the size of gender budgeting has been growing; in 2005-06 the Gender Budgeting Statement covered 10 Demands for Grants covering nine Ministries and Departments with an allocation of 24032 crores (2.79 
percent of the overall budget). This covered 49 demands for grants from 38 ministries in 2019-20, pushing up its magnitude to 142813.3 crores (4.72 percent of the total budget). Gender budget as a percent to total budget was highest during 2011-12, (6.22 percent); but only 4.71 percent of the total budget in 2020-21 (Table 2). This is lower than 4.99 percent in 2018-19 and 5.28 per cent in 2017-18. But the share was more than double the share in 2004-05 (2.3 percent).

Table 2: Magnitude of gender budgeting in India

\begin{tabular}{|c|c|c|c|c|}
\hline Year & $\begin{array}{c}\text { Number of } \\
\text { Ministries }\end{array}$ & $\begin{array}{c}\text { Number of } \\
\text { Demands }\end{array}$ & $\begin{array}{c}\text { The magnitude of Gender } \\
\text { Budgeting (BE) (Rs in crore) }\end{array}$ & $\begin{array}{c}\text { Percentage of Gender } \\
\text { Budgeting to the total budget }\end{array}$ \\
\hline $2005-06$ & 9 & 10 & 24032 & 2.79 \\
\hline $2006-07$ & 18 & 24 & 28736.53 & 5.09 \\
\hline $2007-08$ & 27 & 33 & 31177.96 & 4.5 \\
\hline $2008-09$ & 27 & 33 & 27661.67 & 5.68 \\
\hline $2009-10$ & 28 & 33 & 56857.61 & 6.11 \\
\hline $2010-11$ & 28 & 33 & 67749.8 & 6.22 \\
\hline $2011-12$ & 29 & 34 & 78251.02 & 5.91 \\
\hline $2012-13$ & 29 & 34 & 88142.8 & 5.83 \\
\hline $2013-14$ & 30 & 35 & 97133.7 & 5.46 \\
\hline $2014-15$ & 36 & 39 & 79257.87 & 4.46 \\
\hline $2015-16$ & 35 & 35 & 90624.76 & 4.58 \\
\hline $2016-17$ & 35 & 47 & 117221.47 & 5.28 \\
\hline $2017-18$ & 32 & 48 & 121961.32 & 4.99 \\
\hline $2018-19$ & 38 & 49 & 142813.3 & 4.72 \\
\hline $2019-20$ & 38 & 49 & 143461.72 & 4.71 \\
\hline $2020-21$ & - & - & & \\
\hline $\begin{array}{l}\text { Source: The Government of India's gender budgeting statement and annual report from the Ministry of Women and Child } \\
\text { Development. }\end{array}$ & & & \\
\hline
\end{tabular}

\section{Allocations for women-specific schemes}

Various ministries and departments have introduced certain women-specific programmes like Nirbhaya scheme, programmes for women's safety and security, maternity benefit schemes, programmes for women empowerment and so on that were exclusively meant for making women self-sufficient and for the provision for women safety (Table 3).

Table 3: Allocation for women-specific schemes

\begin{tabular}{|c|c|c|}
\hline Year & Allocation for women-specific (BE) in crore & Percentage share to Gender Budget \\
\hline $2005-06$ & 7905.08 & 32.9 \\
\hline $2006-07$ & 9575.82 & 33.32 \\
\hline $2007-08$ & 8795.47 & 28.21 \\
\hline $2008-09$ & 11459.61 & 27.43 \\
\hline $2009-10$ & 15715.68 & 28.43 \\
\hline $2010-11$ & 19266.05 & 26.26 \\
\hline $2011-12$ & 20548.35 & 26.06 \\
\hline $2012-13$ & 22968.93 & 28.05 \\
\hline $2013-14$ & 27248.29 & 22.33 \\
\hline $2014-15$ & 21887.61 & 21.02 \\
\hline $2015-16$ & 16657.84 & 19.21 \\
\hline $2016-17$ & 17412.01 & 25.75 \\
\hline $2017-18$ & 30184.52 & 20.05 \\
\hline $2018-19$ & 24440.07 & 20.64 \\
\hline $2019-20$ & 29473.52 & 19.91 \\
\hline $2020-21$ & 28568.32 & \\
\hline Source: Annual report of MWCD, various issues, Government of India. & \\
\hline
\end{tabular}


Fund allocation for 100 percent of women-specific programmes covered 32.9 percent of the gender budget in 2005-06. It declined to 28.43 percent in 2010-11 and to 19.91 percent share of the gender budget in 2020-21. The funds are declining year after year and are inadequate to meet gender-specific needs, and the average percentage share of allocation under part $\mathrm{A}$ is 27.91 percent.

\section{Composition of Women-specific programme}

As far as women-specific schemes are concerned, in terms of numbers, there are only three schemes in the Gender Budgeting Schemes with an allocation of more than Rs 1000 crore. Within women-specific schemes, the majority of the expenditure goes to a rural housing, which accounts for around 68.26 percent of women-specific fund allocation and 8.75 percent for maternity benefit schemes (Table 4).

Table 4: Women-specific schemes of government of India (Rs in crore)

\begin{tabular}{|c|c|c|c|c|c|c|c|}
\hline Women-specific schemes & $2014-15$ & $2015-16$ & $2016-17$ & $2017-18$ & $2018-19$ & $2019-20$ & $2020-21$ \\
\hline Beti Bachao Beti Padgao & 90 & 97 & 100 & 200 & 244.73 & 200 & 200 \\
\hline IGMSY & 400 & 438 & 634 & 2700 & 1055 & 2300 & 2500 \\
\hline Hostel for working women & 22.5 & 27 & 28 & 50 & 30.35 & 45 & 150 \\
\hline Nirbhaya fund & 1000 & 2000 & 3000 & 3000 & 848.66 & 851.75 & 855 \\
\hline STEP & 18 & 27 & 30 & 40 & 4.47 & 3.00 & - \\
\hline $\begin{array}{c}\text { National Commission for } \\
\text { Women }\end{array}$ & 18.45 & 25.15 & 25.6 & 25.6 & 22.92 & 25 & 26 \\
\hline ICDS & 16561 & 15502 & 14850 & 16745 & 19234 & 23357 & 27584 \\
\hline Swadhar & 115 & 50 & 100 & - & 25 & 35 & 50 \\
\hline
\end{tabular}

Source: Computed from the budgetary estimates of the Ministry of Women and Child Development in the Gender Budgeting Statements of Government of India.

The Ministry of Women and Child Development is the nodal agency for the implementation of the gender budgeting process. Various women-specific programmes undertaken by the Ministry of Women and Child Development include the Integrated Child Development Programme, Support for Training and Employment Programme (STEP), Rashtriya Mahila Kosh, Swadhar, Rajiv Gandhi Matrithva Sahayog Yojana (SABLA), and the National Commission for the Empowerment of Women. A look at the trends of the scheme on the basis of fund allocation depicts that the allocation to ICDS programmes only shows an increasing trend. The funding allocation to ICDS programmes in 2005-06 was Rs 3315.25 crore, but it was subsequently raised to Rs. 27584 crore in 2020-21 (Table 4).

\section{Pro-women specific programmes}

Pro-women specific programmes include those with at least 30 percent of the allocation for women or benefits reserved for women. Table 5 demonstrates the details about allocation of funds for pro-women specific programmes from $2005-2006$ to $2020-21$.

Table 5: Allocation for pro-women specific schemes

\begin{tabular}{|c|c|c|}
\hline Year & Allocation for pro-women specific schemes (Rs in crore) & Percentage share to Gender Budget \\
\hline $2005-06$ & 16126.92 & 67.10 \\
\hline $2006-07$ & 19160.71 & 66.68 \\
\hline $2007-08$ & 22382.49 & 71.79 \\
\hline $2008-09$ & 16202.06 & 58.57 \\
\hline $2009-10$ & 41141.93 & 72.56 \\
\hline $2010-11$ & 48485.75 & 71.56 \\
\hline $2011-12$ & 57702.67 & 75.94 \\
\hline $2012-13$ & 65173.87 & 71.95 \\
\hline $2013-14$ & 69889.41 & 77.67 \\
\hline $2014-15$ & 76142.23 & 78.98 \\
\hline $2015-16$ & 62600 & 80.79 \\
\hline $2016-17$ & 75212 & 74.25 \\
\hline $2017-18$ & 87036.97 & 79.96 \\
\hline $2018-19$ & 97521.25 & 79.36 \\
\hline $2019-20$ & 11339.78 & 80.08 \\
\hline $2020-21$ & 114893.4 & \\
\hline Source: Government of India's Gender Budgeting Statement, various years & \\
\hline
\end{tabular}


Allocation of funds under Part-B of gender budgeting statements from 2005-06 to 2020-21 is presented in Fig. 2. Except for the year 2008-09, there is a visible increase in the allocations under Part-B of gender budgeting statements. The average percentage share of allocations under Part-B is 72.09 percent. Expenditure under Part $\mathrm{B}$ is more diverse, it is mostly limited to the ministries of education, health, rural development, and women and child development.

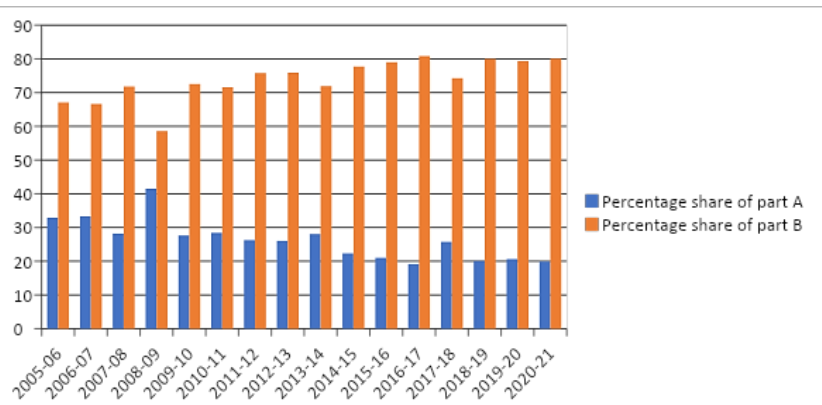

Fig. 2: Percentage share of part $A$ and part $B$ of gender budget in India

The percentage share of allocations under Part-A had always been lower than the allocation under Part-B. Part-B constitutes the maximum portion of the funds under the gender budgeting statement, which is not exclusively for women.

\section{Conclusion}

In India, gender budgeting has drawn significant attention from policymakers. With the production of the gender budgeting statement as part of the Union Budget documents, an institutionalized exertion has been made respond to the fundamental question of how much of the government's total expenditure is flowing to women. In spite of the fact that, the India government's experience of gender budgeting is widely used as a reference point for other gender budgeting initiatives, there seems to be an explicit gap between what was envisioned, and what has been accomplished under the rubric of gender budgeting.

\section{Source of Funding}

None.

\section{Conflict of Interest}

The authors declare no conflict of interest.

\section{Reference}

1. Banerjee N, Roy P (2003), "Gender in Fiscal Policies: A Case of West Bengal”. Snap Shot of Gender Budget Initiative in South Asia, UNIFEM.

2. Banerjee N, Roy P (2004), "What Does the State Do for Indian Women?”. Econ Pol Wkly. 2004;39 (44):4831-7.

3. Chakraborty, Lekha (2013), "A Case Study of Gender Responsive Budgeting in India". Res Report Common wealth Publication: 1-13

4. Gender budgeting handbook (2015), Ministry of Women and Child Development, Government of India.

5. Government of India (2016), Expenditure Budget, Volume 1 (Statement 20).

6. Goyal A (2010), "Women Empowerment through Gender Budgeting- A Review in the Indian Context". Gender Budgeting and Women Empowerment in India (Ed), by Singh A K, Serial Publications: 138-48.

7. Jhamb, Bhoomika, Mishra Y. Gender Responsive Budgeting in India; Time to Ask Questions. Econ Pol Wkly. 2015;50(50):54-62.

8. Menon, Sen, Kalyani, Prabhu SK. The Budget: A Quick Look through a Gender Lens", Economic and Political Weekly, 2001;36(14, 15):1164-9.

9. Mishra Y, Jhamb B. An Assessment of UPA-1 through A Gender Budgeting Lens. Econ Pol Wkly. 2015;44(35):61-8.

10. Vibhuti P. Gendering the Budget at State and National Level and Gender Audit of the Union Budget- A Critical Approach. Urdhva Mula. 2002;1(1):30-57.

11. Misra R. Gender budgeting as a Tool for Women Empowerment. Gender Budgeting and Women Empowerment in India (Ed), Singh AK. Serial Publications: 2010;404-7.

12. Poonam S, Garg P. Women Empowerment through Gender Budgeting in India. Int Res J Hum Resour Soc Sci. 2014;1(6):25-34.

13. Singh, Kumar R. Women Empowerment and Development Discourse in India. Gender Budgeting and Women Empowerment in India (Ed), Singh AK, Serial Publications: 2010;575-92.

14. Singh, Kumar A. An Over View of Gender Budgeting in India. Gender Budgeting and Women Empowerment in India $(E d)$, Singh AK, Serial Publications: 2010;1-39.

15. Singh K. Women Empowerment through Gender Budgeting in India. GJRA - Glob J Res Anal, 2016;5(7):199-201.

16. Soni A. Gender Budgeting: Powerful Tool for Women Empowerment. J Adv Sch Res Allied Educ. 2018;15 (1):4616.

How to cite this article: Smitha EK, Karunakaran N. An overview of gender responsive budgeting in India. J Manag Res Anal. 2020;7(4):167-71. 